\title{
Making Meaning in the Legacy of Tissue Donation for Donor Families
}

\author{
Nancy S. Hogan \\ Loyola University Chicago, nhogan@luc.edu
}

Lee A. Schmidt

Loyola University Chicago, Ischm3@luc.edu

Maggie Coolican

Follow this and additional works at: https://ecommons.luc.edu/nursing_facpubs

Part of the Critical Care Nursing Commons, and the Perioperative, Operating Room and Surgical Nursing Commons

\section{Recommended Citation}

Nancy Hogan, Maggie Coolican, and Lee Schmidt (2013) Making meaning in the legacy of tissue donation for donor families. Progress in Transplantation: June 2013, Vol. 23, No. 2, pp. 180-187.

This Article is brought to you for free and open access by the Faculty Publications and Other Works by Department at Loyola eCommons. It has been accepted for inclusion in Nursing: School of Nursing Faculty Publications and Other Works by an authorized administrator of Loyola eCommons. For more information, please contact ecommons@luc.edu.

\section{(c) $\odot \odot$}

This work is licensed under a Creative Commons Attribution-Noncommercial-No Derivative Works 3.0 License. (C)2013 NATCO, The Organization for Transplant Professionals. 


\section{Making meaning in the legacy of tissue donation for donor families}

Context-Individuals needing lifesaving (heart valves, skin grafts for repair of critical burn injuries) and life-enhancing (corneas, bone and tendon grafts, skin, and veins) tissue donations outnumber the tissues available for transplant.

Objective-To describe the grief family members experienced 6 months after donation and to learn how family decision makers gained meaning from the decision to donate a loved one's tissues. This is phase 1 of a longitudinal study in which family decision makers will be surveyed again at 13 and 25 months after donation.

Design-Qualitative descriptive.

Participants-One hundred seven family decision makers whose family member died a traumatic sudden death and who authorized donating tissues for transplant. Data Collection and Analysis - Data were written responses to the questions, "If you could ask or tell your dead family member something, what would it be?" and "What meaning does donating tissue to others have for you?" Data were analyzed by using content analysis procedures.

Results-Concepts derived from the first question represent the context of family members grieving the sudden death of a loved one. Concepts were (1) feeling empty, (2) missing and loving, (3) being grateful, and (4) having regrets. The concepts derived from the second question were (1) fulfilling their family member's wish, (2) doing the right thing, (3) believing something good came from the death,

(4) helping others, and (5) living on. Reasons for donating were based, in part, on honoring the legacy of their loved ones who had given of themselves to others in life and now continued to give to others after death.

Conclusion - The results of this study provide a basis for health professionals and donation staffs to better understand the context within which families grieve and give meaning to tissue donation. (Progress in Transplantation. 2013;23:180-187)

(C2013 NATCO, The Organization for Transplant Professionals doi: http://dx.doi.org/10.7182/pit2013862

\section{Nancy S. Hogan, RN, PhD, Maggie Coolican, RN, MS, FT, Lee A. Schmidt, RN, PhD}

Loyola University Chicago, Illinois (NSH, LAS), Musculoskeletal Transplant Foundation, East Hampton, Connecticut (MC)

Corresponding author: Nancy S. Hogan, RN, PhD, FAAN, Marcella Niehoff School of Nursing, Loyola University Chicago, 2160 South First Avenue, 105-2846, Maywood, IL 60153

(e-mail nhogan@luc.edu)

To purchase electronic or print reprints, contact:

The InnoVision Group

101 Columbia, Aliso Viejo, CA 92656

Phone (800) 899-1712 (ext 532) or

(949) 448-7370 (ext 532)

Fax (949) 362-2049

E-mail reprints@aacn.org
$\mathrm{E}$ ach year in the United States, an estimated 1 million transplants of donated human tissues are performed and the surgical need for tissues continues to increase. ${ }^{1}$ Tissues donated include heart valves, skin, sclera, corneas, veins, bone, and connective tissue. Donation is not possible without the generosity of families who make a substituted judgment about tissue donation on behalf of a family member or provide medical and social history information for individuals who have stated a wish to donate or joined a donor registry program. Although organ donation is a widely known and an accepted therapy, tissue donation is less so. The public, donor families, and even professionals have less information about tissue donation than about organ donation and about how their processes are distinctly different.

\section{Differences Between Tissue and Organ Donation for Families}

The tissue and organ donation processes differ markedly. The majority of both tissue and donor organ families suffer the sudden, often unexpected death of a loved one due to events such as cardiac arrest, stroke, motor vehicle accidents, drowning, suicide, homicide, and industrial and home accidents. Consequently the death was not expected or anticipated by the family.

However, the organ donor family does have time, often a day or more in the intensive care unit with their loved one, to say the things they need to say, to gather support, and make decisions. These families may have hospital staff supporting them and almost always have staff from the organ procurement organization also 
supporting and meeting their needs. Generally, they are provided donation information, in person by a professional with whom they have met and established a relationship. The family decision maker (FDM) has time to make a donation decision. Within hours or days of the organ recovery, the family is provided organ recipient information and may even be able to establish a relationship with the recipient(s). Some organ donors will also donate tissue.

The tissue donor family has a very different experience. The tissue donor may be the young adult on a motorcycle who dies on the side of the road, the child who drowns in the backyard pool, or the dad who is found dead at home. Often the tissue donor family may not see the family member alive, because of the suddenness of the death. The deceased may not be taken to a hospital but may first be seen by the family at the coroner/medical examiner's office. The tissue recovery agency rarely provides in-person support to a family, and it is standard practice to offer donation information over the telephone. Tissues must be recovered within 12 to 24 hours after the death, so the family must make a donation decision quickly. Although the family may be notified about tissues recovered, it is several months and often close to a year before information about recipients is known and provided to the family. Communication between the tissue recipient and donor family is increasing but may not occur until years after the donation. ${ }^{2}$

\section{Literature Review}

Potential donor family members may be influenced by health care professionals who are responsible for offering them information about donation and the authorization process ${ }^{3-7}$ However, health professionals often feel conflicted about this role because they may believe that donation benefits the recipient but see no benefit for the donor family. ${ }^{8}$ They may have concerns that they will adversely affect the bereavement process by discussing donations with family members. ${ }^{9,10}$ Corr and Coolican ${ }^{11}$ suggest that professionals have important roles in donation and transplant and must be knowledgeable about bereavement, grief, and mourning to better assist FDMs in the process.

\section{Organ Donation}

Extensive research has been conducted in relation to organ procurement, the donation process, and the importance for health professionals to communicate effectively with family members. Siminoff et $\mathrm{al}^{12}$ reported that authorization rates increased approximately $20 \%$ when donation coordinators completed specialized communication training that included effective techniques for initiating the request, gathering and giving information, eliciting donation beliefs, building relationships, and closing the donation discussion. In a study of pediatric organ donor families, many factors influenced donation decisions by parents: parents' registration as organ donors, positive beliefs about donation, exposure to donation information, first mention of donation by a member of a child's health care team, the donation coordinator's sensitivity, time to make the decision, and family agreement about donation. ${ }^{12}$ Decoupling the death notification from the authorization process was also shown to increase the percentage of family members authorizing organ donation from a national average of $40 \%$ to approximately $70 \% .^{13}$

Findings from a study of 22 Greek parents of 14 brain-dead children revealed that the factors that influenced parents' decision to donate organs were (1) conditions of the organ request, (2) parents' prior knowledge about transplant, (3) experience with organ donation, (4) personal factors such as parents' perceived finality of the child's death, and (5) interpersonal factors including the parents' shared agreement to donate their child's organs. ${ }^{14}$ Similarly, researchers found that the type and method of information sharing with donor families may be more important than realized when making donation decisions. ${ }^{15}$ Across these studies, the communication between health care professionals and donor families is a key predictor for whether family members authorize organ and tissue donation.

\section{Tissue Donation}

Fewer studies have addressed tissue donor families, their reasons for donating, and what factors may affect the decision. Siminoff et $\mathrm{al}^{16}$ reported that FDMs who authorize tissue donation are affected by similar factors that influence authorization of organ donation. However, a significant difference included the importance of preparing families about the impending telephone call or first offering donation information in person rather than on the telephone. Grumbley and Pearson ${ }^{17}$ suggested that professionals have a legal and professional responsibility to ascertain donation wishes of the deceased and should incorporate tissue donation into their practice. The Emergency Nurse's Association supports donation and suggests that emergency nurses should actively participate in tissue donation. Although they are in a position to have initial contact with families in crisis, they often have little time to establish relationships. One organ procurement organization initiated a training program for emergency nurses to increase timely referral and authorization rates. Although timely referrals increased, data for increased authorization were not available. However, in reviewing the program, the authors stated that families were receptive to discussing tissue donation in the emergency department. ${ }^{10}$

Researchers have sought to identify factors that motivate family members to authorize tissue donation when a loved one dies, but few studies have addressed 
how family members give meaning to donation when they have had time to reflect on their decision and are immersed in grief. Findings from studies of the reasons why family members are motivated to donate tissues indicate that they are likely to authorize donation if they have explicit verbal or written instructions from their deceased loved one ${ }^{18-23}$ or presume that the donor would have chosen to donate. ${ }^{14}$ Authorization is enhanced if the family members believe that through donation others are given a chance to live or another's suffering and pain are relieved. ${ }^{12,16,19,24}$ An additional motivational factor is a belief among family members that by authorizing donation, part of the donor will live on through the recipient. ${ }^{25,26}$ Corr et $\mathrm{al}^{27}$ reported that this concept may not always be positive and, in fact, can cause secondary grief when an organ fails, the recipient dies, or the tissue cannot be used for transplant.

\section{Donation and the Bereavement Process}

The evidence for the degree to which donation helps or hinders the bereavement process is sparse and conflicting. Some researchers suggest that donation eases the intensity of family members' grief, ${ }^{14,19,28}$ yet findings also show that donation has no impact on helping or hindering how family members grieve. ${ }^{9}$ Cleiren and van Zoelen ${ }^{9}$ measured detachment using the 7-item Leiden Detachment Scale to assess the difficulty of detaching from the deceased and focusing on current demands of life. The authors concluded that consenting to donate organs neither hinders nor facilitates grieving. However, the Leiden Detachment Scale is a measure of detachment not of grief per se, yet authors made claims about grief outcomes. The Cronbach $\alpha$ for this study sample was 0.71 , indicating weak internal consistency. Therefore inferences drawn about detachment from instrument findings should be considered with caution. Neimeyer and Hogan, ${ }^{29}$ in the Handbook of Bereavement Research, cautioned against using nonbereavement measures to draw inferences about the bereavement process. A study ${ }^{30}$ designed to investigate the effects of donation on bereavement, measured by the Core Bereavement Items, showed no significant association between bereavement and upsetting/negative or positive aspects of the donation process. ${ }^{14}$ The psychometrics of the Core Bereavement Items were not provided for this study.

Ballali and Papadatou ${ }^{14}$ conducted a grounded theory study to investigate the grieving processes of donor parents. They concluded that the act of consenting or refusing to consent per se does not affect grief, but the meaning given to donation, and how this meaning affects family members, can help or hinder their bereavement processes.

Hogan and Schmidt ${ }^{31}$ conducted a study to test the Grief to Personal Growth Theory in 167 parents who had authorized their child's organs for donation.
Using the Hogan Grief Reaction Checklist to measure grief $^{32}$ and structural modeling to test the theory findings showed 2 pathways. One theoretical pathway comprised parents who experienced grief and detachment followed by intrusive thoughts and feelings. Later in time, these parents gained the ability to avoid the constant intrusive preoccupation with grief. In the presence of effective social support, parents made meaning out of their suffering, which led them to experience personal growth as an outcome of their suffering. The variable of personal growth is characterized by participants' perception that parents had become more compassionate, tolerant, and forgiving; and they were more caring of others. A second pathway showed some parents became mired in grief and detachment, and they did not show a pathway to personal growth.

In conclusion, research findings on the meaning of authorizing tissue donation and effects on the bereavement processes at 6 months after loss have received little attention from researchers. A comprehensive study is needed that seeks to describe the meaning bereaved family members give to tissue donation and to place meaning within the context of family members grieving the sudden unexpected death of their loved one.

\section{Method and Design}

Data for this study were collected as part of a 5year, longitudinal mixed-method study exploring the bereavement processes of adults who had donated a family member's tissue(s) following his or her sudden death. Data for this report were collected at 6 months after loss. The data collection time period was selected after consultation with donors' family members on the Donor Family Council. Based on their experience, the council members concluded that data collection at 6 months was the appropriate time frame for the first data collection.

Data for this study were collected from 2 openended questions. The first question was developed to capture the meaning of the comment frequently made by bereaved children and adults, "If I could just see him/her one more time." This plea was rewritten as the research question, "If you could ask or tell your dead family member something, what would it be?" The second question was phrased to capture the meaning that FDMs gave to authorizing donation, "What is the meaning of donating your family member's tissues?"

Upon receiving approval from the institutional review board, participants were recruited through the participation of the coordinator of donor family services at a large tissue bank. Potential participants were made aware of this study through a letter that is routinely sent to an identified family member who authorized tissue donation. Participants were informed that study participation involved completing 
several standardized survey questionnaires and providing written responses to 2 open-ended questions.

Participants were sent study materials consisting of a stamped outer envelope, a letter of introduction to the study, an informed consent document, a demographic data sheet, study questionnaires, and a selfaddressed, stamped return envelope.

\section{Sample}

The participants for this study consisted of 107 bereaved adults, 98 (92\%) of whom were white, with $59(55 \%)$ reporting an annual family income greater than $\$ 50000$. Most $(88,82 \%)$ were women, with 49 widows (46\%) and 25 mothers (23\%) whose sons had died. The most common cause of death was traumatic sudden death, for example, cardiac arrest in 72 cases $(67 \%)$ followed by accident in 21 cases $(20 \%)$. Participants reported having some college in 37 cases $(35 \%)$ or were college graduates in 27 cases (25\%). Most participants were Protestant $(47,44 \%)$ or Catholic (37, 34\%), and 93 (87\%) were married at the time of the death. Participants were individuals who provided authorization and/or medical/social history information about the donor, were enrolled in the Donor Family Services Program, and were receiving follow-up support. The participants were offered tissue donation information on the telephone by a tissue donation coordinator trained in the bereavement-centered care philosophy. ${ }^{33} \mathrm{~A}$ few participants had also donated organs and were offered donation information in the hospital by organ procurement or hospital staff.

\section{Data Analysis}

Content analysis procedures were used for analysis of data from the open-ended questions to derive analytic concepts. Content analysis was chosen in order to use a set of procedures designed to make valid inferences from open-ended, written responses to questions in survey research. ${ }^{34}$ Analysis of data started with analysis of the presence of conceptually similar properties. These words, phrases, or sentences were coded for similar properties and assigned a concept name. Names of concepts were revised as more fine-grained nuances emerged from data analysis. Memos were generated throughout the data analysis process to maintain an ongoing account of thoughts and insights related to the analysis of data. The data analysis resulted in 4 context concepts and 5 meaning concepts. Consensus coding was used to determine the 9 concepts. Validity was enhanced through confirmation of the concepts and their properties by the authors (N.H., L.S.) who determined that the concepts were derived directly from participants' data. The final validity check of the data was done by one of the authors (M.C.), who has coordinated after-care programs for donor family members for more than 25 years. The exemplars are direct quotes obtained from the FDMs written responses to the 2 research questions. Names in quotations have been changed to protect the confidentiality of FDMs.

\section{Meaning Making}

The purpose of this study was to learn from FDMs how they find meaning in grieving the sudden death of a loved one and simultaneously make meaning of tissue donation. The search for how bereaved individuals make meaning in their lives after the death of a loved one has recently become the focus of bereavement theorists and researchers. ${ }^{35,36}$

\section{Results for Question 1}

Analysis of the question, "If you could ask or tell your dead family members something, what would it be?" revealed 4 concepts: (1) feeling empty, (2) missing and loving, (3) being grateful, and (4) having regrets. (See Table for bereavement concepts and exemplars.)

Feeling Empty. FDMs described the despair they felt as a result of their family member's death and how his or her absence had left them feeling sad and empty. One participant described this feeling as, "I feel I must go doggedly on, persevering through days that seem flat and dull." Another participant stated, "The house is so empty, it is like the energy, your energy, was sucked out." Participants also described feeling a deep sadness as they contemplated future family events in which the loved one's absence created a void. One mother whose son died stated, "The void from not having you in our lives is enormous and only grows with each new experience I have with my baby." Another participant symbolized the loss as a physical rending of her body and the loved one's effect on others, "You left a huge hole in my heart and one among your family, friends, and community." Another participant concluded "The planet is off kilter without you here."

Missing and Loving. The second concept exemplifies families' continuing bonds to their loved one, often written as a simple declaration, "I miss you and I love you." This professing of love and longing shows the ongoing attachment the family continues to have with the donor. A mother of a newborn infant donor declared "Jason, we miss you more than ever." Some participants answered the hypothetical question with indirect comments, "I would tell her how much we all love her; I'd probably say, 'What's up buttercup?' I would also tell her that we think of her every minute of the day."

Being Grateful. The third concept, being grateful, describes the family members' perception of the donor's positive effect on their life. These memories 
Table Bereavement and donation meaning making concepts and exemplars

\begin{tabular}{|c|c|c|}
\hline Question & Concepts & Examples \\
\hline \multirow{4}{*}{$\begin{array}{l}\text { 1. Bereavement: "If you could ask or } \\
\text { tell your dead family member } \\
\text { something, what would it be?" }\end{array}$} & Feeling empty & $\begin{array}{l}\text { "You left a huge hole in my heart and one among your } \\
\text { family, friends and community." }\end{array}$ \\
\hline & Missing and loving & "I miss you and I love you." \\
\hline & Being grateful & $\begin{array}{l}\text { "Thank you for taking such good care of me before and } \\
\text { after death." }\end{array}$ \\
\hline & Having regrets & $\begin{array}{l}\text { "I didn't tell him often enough how special he was and } \\
\text { how much I loved him." }\end{array}$ \\
\hline \multirow{5}{*}{$\begin{array}{l}\text { 2. Donation: "What meaning does } \\
\text { donating tissue to others have for } \\
\text { you?" }\end{array}$} & $\begin{array}{l}\text { Fulfilling their family } \\
\text { member's wish }\end{array}$ & $\begin{array}{l}\text { "I feel comfortable knowing that I did exactly as she } \\
\text { wanted according to her living will." }\end{array}$ \\
\hline & Doing the right thing & "I am glad I had a chance to do the right thing." \\
\hline & Helping others & $\begin{array}{l}\text { "My son was a giving, caring person so to donate tissues } \\
\text { means that he is still caring, giving something of himself." }\end{array}$ \\
\hline & $\begin{array}{l}\text { Believing something good } \\
\text { came from the death }\end{array}$ & "It helps to make a senseless death less awful." \\
\hline & Living on & $\begin{array}{l}\text { "By donating my husband's tissue, I feel that he is help- } \\
\text { ing others to live their lives and therefore he will be } \\
\text { alive for a long time to come." }\end{array}$ \\
\hline
\end{tabular}

were cherished by participants. For example, one person expressed gratitude that the donor had been a positive force in the family member's life and the lives of others. "He helped me to be and achieve more than I ever thought I could. He helped me to be a better person." Another person wrote, "I'm so fortunate to have [been] married to you." Another participant wrote, "You were a joy to love." Other examples of the family members' memories of the donors' positive qualities were, "You left only good memories, and that has helped to make life easier for me and your family and friends," and "You were a wonderful mother and sister. Because of your guidance, their path may be easier." One participant expressed gratefulness that extended after death by writing, "Thank you for taking such good care of me before and after death."

Having Regrets. The concept, having regrets, was characterized by a few family members' comments about missed opportunities that could never be rectified because of the donor's unanticipated, sudden death. Some family members blamed themselves for failing to tell the donor how much he or she was loved often enough. "I didn't tell him often enough how special he was and how much I loved him." Another participant simply wrote, "I am sorry I wasn't more understanding."

Some participants regretted that they hadn't done more for the donor or talked more often to their loved one "I wish I would have known you were going to die. I would have done more for you, talked more to you." One mother expressed remorse that she hadn't been kinder and more understanding toward her son throughout his life. "Dear one, I wish I'd known the extent of your suffering, and I wish I would have been more careful with your emotions as a child."

In summary, findings from question 1 describe the grief that family members were experiencing 6 months after donation. Participants described their sense of emptiness as a result of their family member's physical absence. They declared their continuing bond to their loved one by confirming their love. They expressed gratefulness for the positive memories of the donor and his or her influence on themselves and others. Some participants had negative memories that were painful as they shared regrets that they had not been kinder, more understanding, and more loving toward the donor.

\section{Results for Question 2}

Analysis of the question, "What meaning does donating tissue to others have for you?" revealed 5 concepts: (1) fulfilling their family member's wish, (2) doing the right thing, (3) believing something good came from the death, (4) helping others, and (5) living on through others. (See Table for donation concepts and exemplars.)

Fulfilling Their Family Member's Wish. A first meaning concept was conceptualized as fulfilling the donor's wish. Participants reported that they agreed to donation as a result of explicit instructions left by the donor or that they presumed that the donor would have agreed to donation had he or she been asked. Participants who were aware of their family member's wish regarding donation found meaning in fulfilling 
the loved one's wish. Those participants who knew of their loved one's desire to donate found solace. One widower described how he was consoled by knowing his spouse's desires, "I feel comfortable knowing that I did exactly as she wanted according to her living will." A widow declared, "Donating was the fulfillment of my husband's wish." The word "honoring" was mentioned by some participants, "My daughter listed herself as a donor and I was able to honor her wish."

Some participants who did not know the loved one's opinion about donation made the decision to donate on the basis of their presumption that the donor would have chosen to donate had he or she been asked. "He would have approved." A mother stated that her infant donor would have wanted his tissues donated: "He would have wanted others, especially children, to have a better life because he had lived."

Doing the Right Thing. The second concept, doing the right thing, was based on the participant's belief that donation was simply "the right thing to do." One mother stated, "It was just the right thing to do to help another in need." A participant whose husband died indicated that although she had not thought about donation herself, she was grateful that she had been offered the opportunity to donate her husband's tissues. She simply said, "I'm glad I had a chance to do the right thing." Another participant viewed donation as the morally right thing to do: "If his tissues can help some other person and give them a chance at life then it would have been incredibly selfish not to donate."

Helping Others. The third concept refers to the belief held by many family members that donation was in keeping with the donor's philosophy of helping others throughout his or her lifetime. They perceived donation as a natural extension of the loved one's lifetime commitment to generously helping others. A wife wrote, "Ben is still helping people like he did when he was alive." A mother reasoned, "My son was a giving, caring person, so to donate tissues means that he is still caring, giving something of himself." A father wrote directly to his son, "You were always helping others and now you help someone to see, hear, recover, and have a good life." A daughter reported that the decision to donate was based on its compatibility with her mother's personality. "She was a very warm, generous, and giving person and her tissue donating ... fits her personality and the person who she was." A mother explained that, "donation gives someone the chance to live on. It is very important to burn victims." A wife stated, "I believe someone sees because of him."

\section{Believing Something Good Came From the Death.} The fourth meaning concept originates from the fact that family members found themselves believing that something good came from the death. It was important to them that out of the tragedy of their loved one's death something positive had resulted that eased their pain. One participant addressed her son directly by saying, "It was a comfort to me that something good came out of your death." A father declared that donation made his grief and suffering less difficult to bear, "It helps to make a senseless death less awful." One mother stated that donating her child's tissues gave value to her child's life, "It makes my child's life worth something." One father gave meaning to his child's death by saying, "It only makes sense that such a senseless death benefit someone else." The most common phrase used to describe believing something good had come from donation was that he or she "did not die in vain."

Living On. The fifth concept reflects how participants gave meaning to donation by believing that the loved one was living on through the recipient or that a part of the donor was living on. Some family members stated that the donor was living on through transplant. For example, a father wrote "Jill's life ended, yet she lives on, she would like that." Another participant declared, "He is now living on in other people." A wife wrote, "By donating my husband's tissues, I feel that he is helping others to live their lives and therefore he will be alive for a long time to come." Alternatively, other family members believed that part of the donor was living on through the recipient. A mother whose infant died provided this example, "It means part of her is still in this world." Another mother was comforted by the belief that, "At least a part of Danny is living on." In both of these ways, the participants acknowledged the fact of the death and were comforted by giving meaning in the belief that their loved one or part of their loved one continued living on through the recipient.

\section{Discussion}

These results provide a framework for understanding how family members grieve and give meaning to their family member's legacy through donating tissues. To date, most studies pertaining to donor family members have focused on the motivating factors at the time of death that influence the decision that leads to authorizing donation..$^{9,12,37}$ Fewer studies have investigated grieving family members' motivations to donate after they have had time to reflect back on the donation decision..$^{19-38}$ Although donation is inextricably entwined with the bereavement process, a comprehensive description of how these 2 phenomena affect the meaning family members give to donation has been notably absent in the literature.

The concepts derived from the question, "If you could ask or tell your loved one something, what 
would it be?" showed that family members continued feeling empty. Their thoughts and feelings of sadness, emptiness, and a sense of being physically spent characterized the pain and suffering they felt. The despair of experiencing the permanent physical absence of their loved one while simultaneously sensing a continuing existential presence was expressed through their comments of continuing to miss and love him or her. This finding is supported by the missing and loving category, revealing that family members have an ongoing attachment to the deceased. They expressed feeling grateful for the positive memories they had of the donor's character and personality. They felt gratitude that the donor had been a positive force in the participants' lives and in the lives of others. A few family members expressed having regrets about perceived commissions or omissions in their relationship with the deceased family member. The concepts of missing and loving and of having regrets have been reported in previous bereavement research ${ }^{39}$ These findings represent the context of grieving from which participants addressed the meaning question.

Findings from the question "What is the meaning of donating your family member's tissues?" showed that for some participants donation meant fulfilling their family member's wish. Family members were thankful to have had explicit written or verbal instruction from the donor because they did not have to make an independent decision to authorize donation. This finding has previously been reported in the literature..$^{14,19,21,23}$ Family members who authorized donation without knowledge of the donor's wish often based their decision on their presumption that if the donor had been asked, he or she would have consented. This finding has also been reported in a parental donation study. ${ }^{14}$ Some family members reasoned that authorizing donation was simply a matter of doing the right thing. Another finding, believing that something good could come from the death and salvaging something positive out of something so tragic, also motivated family members to choose donation. This finding supports those of Jacob and Klacznski's research..$^{40}$

Families attributed the act of donation to wanting to help others by easing the recipient's pain and suffering. Family members reported on their belief that the loved one or part of the loved one lived on through the recipient and expressed that the sense that the donor continued to live on was comforting. This finding has been reported previously..$^{14,16,39,41}$ Unique findings from this study show that FDMs are motivated to donate, in part, to continue the donor's lifetime legacy of caring for others after death.

The literature review of study findings did not provide compelling evidence to settle the question about the degree to which donating tissues helps or hinders the bereavement process. However, participants in this qualitative study expressed feeling comforted by donating their family member's tissues. Evidence showed that participants were comforted by knowing that (1) they had fulfilled the donor's wish to donate, (2) they had done the right thing, (3) something good had came from the death, (4) they had helped others, and (5) donation had allowed their loved one or part of their loved one to live on. Researchers in several other qualitative studies have reported that family members gave positive meaning to donation and that agreeing to donation had helped to ease the pain of losing their loved one..$^{42,43}$

\section{Limitations}

Findings and interpretations for this study need to be considered in terms of the following limitations. The data were collected at 6 months after death, and it is possible that participants would have given different responses if data had been collected at a different time point, and data were not reviewed by independent FDMs. However, one of the authors (M.C.) is a donor parent and has been a family donor coordinator for both organ and tissue organizations for more than 25 years. She was involved in all phases of data collection, analysis, and interpretation. Finally, ideally, we would have included a similar size sample of organ donors to identify if uniquely different findings from organ donor FDMs would result.

\section{Conclusion}

This study provides a comprehensive framework for understanding the meaning that family members give to grieving and tissue donation 6 months after death. The study confirms the importance to a family about knowing the donation wishes of a loved one so they can honor those wishes at the time of death. Providing this information to the public may be helpful in promoting donor registries.

The study also reinforces the concept that many families believe that their loved one is living on in a recipient. This may or may not be positive and there may be a need for further investigation to determine the impact on the grieving family when an organ fails, a recipient dies, or tissue cannot be used for transplant.

The findings may also help to diminish the concerns of professionals in hospitals or medical examiner/ coroner offices that providing families with information on tissue donation at the time of a loved one's death will have an adverse effect on the bereavement process. Instead, the results may empower the professionals to be more comfortable as they offer family members information and support. The findings may also encourage professionals who work in donation to seek more information and understanding of the responses of grieving families to help provide them with the information and support they need. 


\section{Financial Disclosures}

This study was partially supported by the Musculoskeletal Transplant Foundation.

\section{References}

1. Understanding Donation. Statistics. http://www.donatelife .net. Accessed September 18, 2012

2. Haire MC, Hinchliff JP. Donation of heart valve tissue: seeking consent and meeting the needs of donor families. Med $J$ Aust. 1996;164(1):28-31.

3. Gallup Organization. The American Public's Attitudes Toward Organ Donation and Transplantation. Boston, MA: The Partnership for Organ Donation and Harvard School of Public Health; 1993.

4. Nasrollahzadeh D, Siavosh H, Ghods AJ. Intensive care unit nurses' attitudes and knowledge toward brain death and cadaveric renal transplantation in Iran. Transplant Proc. 2003; 35(7):2545.

5. Saviozzi A, Bozzi G, DeSimone P, Filipponi F. Efficiency of the tissue procurement process: what evaluation tools? Transplant Proc. 2010;42(6):2195-2196.

6. Shabanzadeh AP, Sadr SS, Ghafari A, Nozari BH, Toushih M. Organ and tissue donation knowledge among intensive care unit nurses. Transplant Proc. 2009;41(5):1480-1482.

7. Tebourski F, Jaouadi N, Ben Alaya D, Benamar-Elgaaied A, Ayed M. Attitude of health personnel to organ donation and transplantation. Tunis Med. 2003;81(7):482-487.

8. Bredehorn T, Langer C, Eichhorst A, Bormke D, Wachsmuth C. Questioning the relatives for organ and tissue donation. Transplant Proc. 2002;34(6):2353-2354.

9. Cleiren MP, Van Zoelen AA. Post-mortem organ donation and grief: a study of consent, refusal and well-being in bereavement. Death Stud. 2002;26(10):837-849.

10. Sebach AM, McDowell D. Developing a tissue donation advocacy program in a rural emergency department. $J$ Emerg Nurs. 2011;38(1):63-68.

11. Corr CA, Coolican MB. Understanding bereavement, grief, and mourning: implications for donation and transplantation professionals. Prog Transplant. 2010;20(2):169-177.

12. Siminoff LA, Marshall HM, Dumenci L, Bowen G, Swaminathan A, Gordon N. Communicating effectively about donation: an educational intervention to increase consent to donation. Prog Transplant. 2009;19(1):35-43.

13. Razek T, Olthoff K, Reilly PM. Issues in potential organ donor management. Surg Clin North Am. 2000;80(3):1021-1032.

14. Bellali T, Papadatou D. Parental grief following the brain death of a child: does consent or refusal to organ donation affect their grief? Death Stud. 2006;30(10):883-917.

15. Long T, Sque M, Addington-Hall J. Conflict rationalization: how family members cope with a diagnosis of brain stem death. Soc Sci Med. 2008;67(2):253-261.

16. Siminoff LA, Traino HM, Gordon, N. Determinants of family consent to tissue donation. J Trauma. 2010;69(4):956-963.

17. Grumbley E, Pearson J. Tissue donation: benefits, legal issues and the nurse's role. Nurs Stand. 2006;21(1):51-56.

18. Burroughs TE, Hong BA, Kappel DF, Freedman BK. The stability of family decisions to consent or refuse organ donation: would you do it again? Psychosom Med. 1998;60(2):156-162.

19. Merchant SJ, Yoshida EM, Lee TK, Richardson P, Karlsbjerg $\mathrm{KM}$, Cheung E. Exploring the psychological effects of deceased organ donation on the families of the organ donors. Clin Transplant. 2008;22(3):341-347.

20. Rodrigue JR, Cornell DL, Howard RJ. Pediatric organ donation: what factors most influence parents' donation decisions? Pediatr Crit Care Med. 2008;9(2):180-185.
21. Stouder DB, Schmid A, Ross SS, Ross LG, Stocks L. Family, friends, and faith: how organ donor families heal. Prog Transplant. 2009;19(4):358-361.

22. Walker JA, McGrath PJ, MacDonald NE, Wells G, Petrusic W, Nolan BE. Parental attitudes toward pediatric organ donation: a survey. CMAJ. 1990;142(12):1383-1387.

23. Wilson P, Sexton W, Singh A, et al. Family experiences of tissue donation in Australia. Prog Transplant. 2006;16(1):52-56.

24. Morse JM, Carter BJ. Strategies of enduring and the suffering of loss: modes of comfort used by a resilient survivor. Holist Nurs Pract. 1995;9(3):38-52.

25. Douglass GE, Daly M. Donor families' experience of organ donation. Anaesth Intensive Care. 1995;23(1):96-98.

26. Gordon AK, Herzog A, Lichtenfeld D. Surveying donor families: a comparison of two organ procurement organizations. Clin Transplant. 1995;9(3 pt 1):141-145.

27. Corr CA, Coolican MB, Moretti LS, Simon R. Donor families, distinctive secondary losses and "second death" experiences. Prog Transplant. 2011;21(3):220-227.

28. Niday P, Painter C, Peak J, et al. Family and staff responses to a scripted introduction to tissue donation for hospice inpatients on admission. Prog Transplant. 2007;17(4):289-294.

29. Neimeyer RA, Hogan NS. Qualitative or quantitative issues in the study of grief. In: Stroebe MS, Hansson RO, Stroebe W, Schut H, eds. Handbook of Bereavement Research: Consequences, Coping, and Care. Washington, DC: American Psychological Association Press; 2001:89-118.

30. Burnett P, Middleton W, Raphael B, Martinek N. Measuring core bereavement phenomena. Psychol Med. 1997;27(1):49-57.

31. Hogan NS, Schmidt LA. Testing the grief to personal growth model using structural equation modeling. Death Stud. 2002; 26(8):615-634.

32. Hogan NS, Greenfield DB, Schmidt LA. The development and validation of the Hogan Grief Reaction Checklist. Death Stud. 2001;25(1):1-32.

33. Core C, Coolican M, eds. Bereavement Centered Care and the Assisted Approach: A Resource Manual for Tissue Donation. Edison, NJ: Musculoskeletal Transplant Foundation; 2008.

34. Krippendorff K. Content Analysis: An Introduction to Its Methodology. Thousand Oaks, CA: Sage; 2004.

35. Lichtenthal WG, Currier JM, Neimeyer RA, Keesee NJ. Sense and significance: a mixed methods examination of meaning making after the loss of one's child. J Clin Psychol. 2010;66(7): 791-812.

36. Waters G, Wilcox S. Making meaning. Behav Brain Sci. 2002;25(5):644-645.

37. Rodrigue JR, Scott MP, Oppenheim AR. The tissue donation experience: a comparison of donor and nondonor families. 2003;13(4):258-264.

38. Bellali T, Papazoglou I, Papadatou D. Empirically based recommendations to support parents facing the dilemma of paediatric cadaver organ donation. Intensive Crit Care Nurs. 2007;23(4):216-225.

39. Hogan N, DeSantis L. Adolescent sibling bereavement: an ongoing attachment. Qual Health Res. 1992;2(2):159-177.

40. Jacobs JE, Klaczynski PA. The Development of Judgment and Decision Making in Children and Adolescents. Mahwah, NJ; Lawrence Erlbaum Associates; 2005.

41. Shih FJ, Lai MK, Lin MH, et al. Impact of cadaveric organ donation on Taiwanese donor families during the first 6 months after donation. Psychosom Med. 2001;63(1):69-78.

42. Sque M, Payne SA. Dissonant loss: the experiences of donor relatives. Soc Sci Med. 1996;43(9):1359-1370.

43. Sque M, Long T, Payne S. Organ donation: key factors influencing families' decision-making. Transplant Proc. 2005;37(2): 543-546. 
Copyright of Progress in Transplantation is the property of North American Transplant Coordinators Organization, Inc. (NATCO) and its content may not be copied or emailed to multiple sites or posted to a listserv without the copyright holder's express written permission. However, users may print, download, or email articles for individual use. 